\title{
Фитосанитарная обстановка и влияние пестицидов на формирование урожая в агроценозах новых сортов яровой пшеницы
}

\author{
Слободчиков А.А. \\ СибНИИРС - филиал Института ичитологии и генетики СО РАН, Новосибирск, Россия \\ e-mail: slobodchikov@bionet.nsc.ru
}

Для реализации потенциала новых сортов пшеницы в сельскохозяйственном производстве, важно иметь информацию об их групповой или комплексной устойчивости к вредным организмам и их отзывчивости на внесение пестицидов в различных условиях выращивания. Такая информация позволит оптимизировать элементы системы защиты для каждого отдельно взятого сорта пшеницы, сократить затраты и повысить рентабельность производства, улучшить экологическую обстановку окружающей среды. Сравнительную оценку фитосанитарной ситуации в посевах сортов мягкой яровой пшеницы (раннеспелый - Новосибирская 16, среднеранние - Новосибирская 41 и Сибирская 21) проводили в 2018 г. на стационаре СибНИИРС - филиал ИЦиГ (в ОПХ «Элитное»). Наши исследования показали некоторые различия пораженности посевов пшеницы болезнями и заселенности их вредителями. Сорт Новосибирская 16 сильнее других поражался обыкновенной корневой гнилью (6.8\%), бурой листовой ржавчиной $(5.2 \%)$ и септориозом (3.5\%), его посевы интенсивнее повреждались внутристеблевыми вредителями, однако меньше их заселяли хлебная полосатая блошка (164 шт./м²) и пшеничный трипс (59 личинок/колос). Растения пшеницы Новосибирская 41 слабее других поражались обыкновенной корневой гнилью $(2.1 \%)$ и повреждались внутристеблевыми вредителями, в большей степени поражались мучнистой росой $(10.1 \%)$ и заселялись хлебной полосатой блошкой (252 шт./м²). Сорт Сибирская 21 проявил самую высокую устойчивость к листостебельным болезням (индекс развития болезней составил 0.4-1.2 \%) и был менее привлекательным для пшеничного трипса (18 личинок/колос). Также он показал самую высокую урожайность, как без применения фунгицидов и инсектицидов (5.13 т/га), так и с их использованием в различных сочетаниях (от 5.27 до 6.19 т/га). Наименьшую урожайность отмечали у сорта Новосибирская 16, в первом случае она составила 2.87 т/га, во втором - изменялась от 3.26 до 4.06 т/га. Продуктивность сорта Новосибирская 41 варьировала в зависимости от варианта от 3.91 до 5.77 т/га. Таким образом, изучаемые сорта определенным образом влияют на формирование фитосанитарной ситуации в отношении болезней и вредителей, по-разному отзываются на внесение пестицидов и дают различную прибавку урожая при их внесении. 